\title{
Local sediment sources and palaeoflow directions in Upper Miocene turbidites of the Pannonian Basin System (Croatian part), based on mapping of reservoir properties
}

\author{
Kristina NOVAK ZELENIKA ${ }^{1, *}$, Josipa VELIĆ ${ }^{2}$ and Tomislav MALVIĆ ${ }^{1,2}$ \\ 1 INA-Industry of Oil, Plc. Exploration and Production of Oil and Gas, Sector for Geology and Reservoir Management, \\ Šubićeva 29, 10000 Zagreb, Croatia \\ 2 Faculty of Mining, Geology and Petroleum Engineering, University of Zagreb, Pierottijeva 6, 10000 Zagreb, Croatia
}

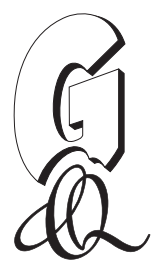

Novak Zelenika K., Velić J. and Malvić T. (2013) Local sediment sources and palaeoflow directions in Upper Miocene turbidites of the Pannonian Basin System (Croatian part), based on mapping of reservoir properties. Geological Quarterly, 57 (1): 16-30, doi: 10.7306/gq.1068

The source of the clastic sediments in the Croatian part of the Pannonian Basin System (CPBS) during the Late Pannonian and Early Pontian was the Eastern Alps. Clastic sediments were redeposited several times before they reached the Sava Depression. The depositional environment and sediment transport mechanisms have been subject to detailed analysis described in many publications, and this study builds on previous research. We have carried out geostatistical mapping of selected Upper Pannonian and Lower Pontian reservoir variables of the Kloštar Field, located to the west of the Moslavačka gora Mt. (Croatia). This has shown that the Moslavačka gora Mt. was a secondary, local source of sediment, in contrast to the previous interpretation of a single, distant clastic source (Eastern Alps) for the CPBS during the Late Miocene. As the mineralogical composition of the Moslavačka gora Mt. and the Eastern Alps is very similar, the dominant direction of turbidity currents obtained by sequential indicator simulations are used to suggest that a modest amount of detritus was eroded from the Moslavačka gora Mt. and mixed with detritus sourced from the Eastern Alps.

Key words: sequential indicator simulations, Upper Miocene sandstones, turbidites, Croatia, Sava Depression, reservoirs.

\section{INTRODUCTION}

Definition of source material is important for the proper description of the depositional environment and of active detritus transport mechanisms. Local uplifted areas may be the main clastic material sources, as seen in the Pliocene and Quaternary deposits of the Sava Depression. However, during the Miocene the entire Pannonian Basin System (PBS) was mainly fed from two, major clastic sources located in the Alps and Carpathians, although across that area several prominent palaeo-uplifted structures existed. Such local uplifted "mountains" may provide material which is mineralogically distinct from that coming from the Alps and Carpathians. In this case transport directions should also indicate local "mountains" as a detritus source and local transport directions should be different from the regional direction.

In our case, a local source of psammitic clastics may have provided material of a different grain size than that which had its origin in the Alps, hence affecting the effective porosity of Upper Miocene sandstones. Those sandstones are defined as hydro-

\footnotetext{
* Corresponding author: Kristina.NovakZelenika@ina.hr
}

Received: May 14, 2012; accepted: August 10, 2012; first published online: January 25, 2013 carbon reservoirs with properties different in part to those from areas far from other uplifted palaeostructures in the Sava Depression.

The importance of local material source in hydrocarbon reservoirs has been previously described. For example, Hailwood and Ding (2000) showed that in the Britannia Field, sediments were derived from lateral sources located on structural highs rather than being dispersed by axial regional flow along the Witch Ground Graben (North Sea). A local source of material was also dominant at some locations in the marginal eastern part of the Sava Depression. Kovačić et al. (2011) described the sedimentology of Neogene strata of the Dilj gora Mt. According to those authors, the Middle Miocene deposits contain clastic detritus composed of granitoids and metamorphic and sedimentary rocks, all attributable to the nearest mountains, such as the Papuk, Psunj, Požeška gora or Motajica Mts. At the very east of the PBS, in the Transylvanian Basin, the lithofacies were described in detail by Krezsek and Filipescu (2005) and by Krezsek et al. (2010). They divided the lithofacies into several facies associations from fluvial (massive conglomerate, stratified conglomerate, gravel lag, stratified sandstone, shale and fine sandstone), shallow marine ramp (conglomerate, pebbly sandstone, coarse sandstone, bioclastic sandstone and shale, marls with coarse and fine-grained sandstone), delta fan (bipartite conglomerate and sandstone, pebbly sandstone and sandstone), deep-water (massive sandstone and conglomerate, sandstone with minor marl, marls with minor sandstones, 
marls) and evaporite (gypsum, halite). There is some similarity between the fluvial facies in the Transylvanian Basin (Romania), described by Krezsek et al. (2010) and those described by Vrbanac et al. (2010) for the western part of the Sava Depression (Croatia), which comprise the following facies: thick-bedded to massive sandstone; thinly-bedded sandstone; laminated sandstone, siltstone and marl; and massive marls (Malvić, 2012). According to the Krezsek et al. (2010) turbidite mechanisms in the Transylvanian Basin were active in the Late Badenian. The Sarmatian is thought to span the transition from shallow marine to deltaic sedimentation. The lithology of the Pannonian deltas includes sandstones and marls. Deep-water sandstones, deposited by turbidity currents, form the main hydrocarbon reservoirs, which can be compared with Upper Miocene turbidite (but shallow-water) sandstone reservoirs in the Sava Depression (Croatia).

Turbidity currents were a dominant clastic transport mechanism in the Croatian part of the Pannonian Basin System (CPBS), during the Late Pannonian and Early Pontian (e.g., Rögl and Steininger, 1984; Rögl, 1996, 1998). During these periods the main sandstone hydrocarbon reservoirs were deposited (Velić, 2007). Neogene deposition in the CPBS has been widely described (e.g., Royden, 1988; Velić et al., 2002; Malvić et al., 2005; Ćorić et al., 2009; Vrbanac et al., 2010;
Velić et al., 2011). The Late Pannonian and Early Pontian intervals belong to the second transtensional phase (Malvić and Velić, 2011), when thermal subsidence generally re-opened many depressional areas along the entire PBS and created depositional spaces for the accommodation of a large volume of sandy material. Subsidence allowed for the accumulation of Upper Pannonian and Lower Pontian strata, with thicknesses up to $1000 \mathrm{~m}$, and maintained a relatively stable and shallow lake environment (Vrbanac et al., 2010; Malvić and Velić, 2011).

Transported detritus had been eroded in the Eastern Alps (Fig. 1), deposited in the Vienna Basin and from that point, turbidite material was re-deposited several times before it entered the Sava Depression across the regional structure that forms a saddle between the Kalnik and Moslavačka gora Mts. Then it reached the present-day Kloštar Field, which was just a few kilometres to the south-west of the Moslavačka gora Mt. (Fig. 1). In the Late Pannonian, regional channels dominated inside the Sava Depression (Vrbanac, 2002) and they were sites of sand deposition, but during the Early Pontian additional strike-slip faults opened. The consequence of such faulting was the Kloštar structure, located along marginal uplifted palaeorelief areas. The main direction of turbidity currents in the Late Pannonian and Early Pontian was north-

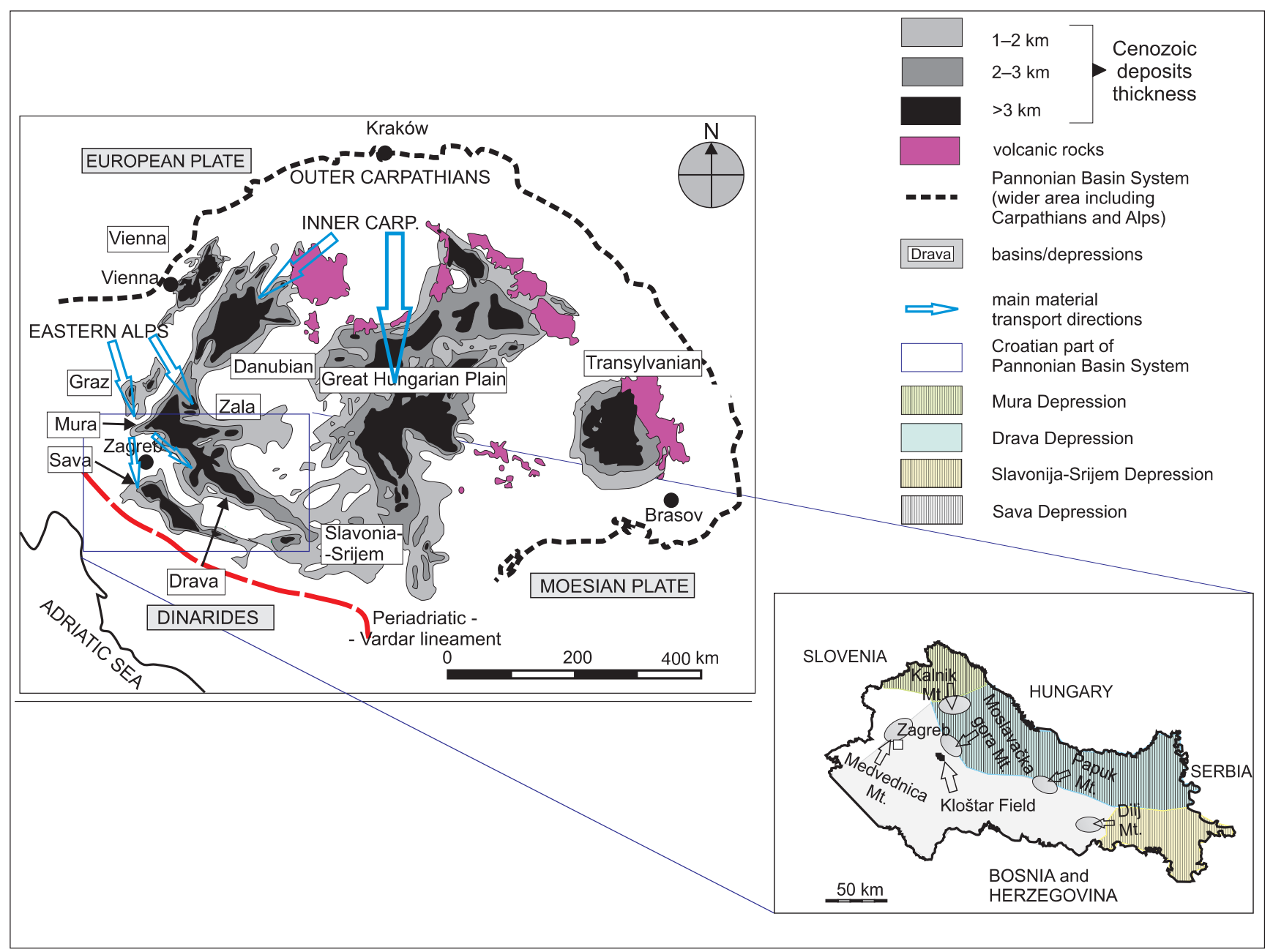

Fig. 1. Pannonian Basin System with regional material transport directions and location of the Croatian part of the Pannonian Basin System 
west-southeast (Vrbanac et al., 2010), with the largest thicknesses of deposited material in the deepest parts of the lake. Vrbanac (2002) and Vrbanac et al. (2010) considered that in the Late Pannonian the lake was more than $200 \mathrm{~m}$ deep, and the Moslavačka gora horst was below water level. However, in the Early Pontian, due to continued overall shallowing, it probably rose above the lake level. This scenario is indicated by present-day geological outcrops on the higher part of this mountain, where Pannonian and Pontian deposits are missing. This absence may reflect:

- Pliocene and Quaternary uplift and consequent complete erosion of the Upper Miocene;

- erosion during the Pannonian and Pontian.

The Moslavačka gora Mt. and lake level palaeoreconstruction suggest that the palaeomountain was a minor, but active, local source of detritus. This is especially valid for marginal depressional structures such as the Kloštar Field and it may explain the differences in location of Upper Pannonian and Lower Pontian reservoir sandstone lithofacies as well as their slightly different mineralogical content.

The proximity of the Moslavačka gora Mt. suggests that some sandy detritus was eroded and transported within the alluvial fans, mixed with Alpine turbidite clastics and eventually deposited in the present-day reservoirs. Thus, a north-south trend, resulting from alluvial transport, should be recognisable in all related reservoir variables of the Kloštar structure, and it should be potentially useful for the recognition of palaeocurrent directions. Such variables are porosity and the thickness of sandstones, which trends are searched for on geostatistical maps and calculated by Sequential Indicator Simulations (SIS).

The Kloštar Field has been chosen for the analysis, because it is the best explored structure within the Sava Depression. It is located about $35 \mathrm{~km}$ east of Zagreb, on the western slope of the Moslavačka gora Mt. All conclusions based on the results obtained in the Kloštar Field appear applicable to the entire Sava Depression, or at least to its western part where numerous similar (as regard reservoir size and age) fields exist. Furthermore, the Sava Depression is a typical marginal basin inside the Pannonian Basin System, so the Late Miocene depositional mechanisms described are probably valid in all other marginal parts of that system.

\section{GENERAL NEOGENE-QUATERNARY TECTONICS AND DEPOSITIONAL MODEL OF THE SAVA DEPRESSION}

The Neogene succession can be divided into three depositional megacycles (Velić et al., 2002) which are locally separated by unconformities. The first megacycle between the Neogene basement and the top of Sarmatian strata belongs to syn-rift and early post-rift phases of the Pannonian Basin System or to the first transtension and first transpression phase (according to Malvić and Velić, 2011). Graben and pull-apart structures are characteristic of that phase. Deposits of the second megacycles were deposited during post-rift thermal subsidence (re-extension) or the second transtensional phase. The third megacycle deposits formed due to basin inversion in the Pliocene and Quaternary. Compression (or the second transpressional phase) caused uplift, erosion, reactivation and character change of the normal faults as well as the creation of pop-up structures.
Evolution of the Sava Depression (Fig. 2) began in the Early Miocene with sporadic lacustrine deposition. Marine transgression occurred in the Early Badenian when sediments of the Prečec Formation were deposited (Ćorić et al., 2009). Its development continued during the whole of the Miocene, Pliocene and finally Quaternary, when the present day relief was formed during the second transpressional phase (Malvić and Velić, 2011). During the Pliocene most of the traps were formed and filled with hydrocarbons (Velić, 2007). During the Sarmatian, the connection between the Paratethys and Tethys was broken. Terrestrial influence increased, turning the marine environment into brackish and later into freshwater during the Pannonian and Early Pontian and finally alluvial and terrestrial during the Late Pontian, Pliocene and Quaternary (Fig. 2). Therefore, after Sarmatian and Pannonian sea became a Pannonian lake. The highest present-day mountains, such as Medvednica and Papuk, remained above sea/lakelevel (Vrbanac et al., 2010) during the entire Middle and Late Miocene. The position of the lower ones, such as Moslavačka gora (today the peak is at $489 \mathrm{~m}$ a.s.l.) or Dilj (461 $\mathrm{m}$ a.s.l.) Mts., is uncertain, i.e. it is not surely known if they formed subwater highs during the entire Late Miocene, or certain times they also existed as islands.

After the first transpressional phase and shallowing of the entire CPBS, several isolated or temporarily connected lakes were formed, during a period of regional and long-lasting brackish depositional conditions. This was during the second transtensional phase, when large quantities of sand and silt were deposited as a result of periodic turbidity current activity. Two lithostratigraphic units belong to those substages. Those are the Upper Pannonian Ivanić-Grad Formation and Lower Pontian Kloštar Ivanić Formation (Fig. 2). In calm periods, the depressions were filled with mud and calcitic clay, resulting basinal marls, after compaction (Fig. 2).

This palaeogeographical situation lasted until the end of the Early Pontian. A single lake was reduced to several smaller ones. Freshwater areas such as marshes and swamps existed during the Pliocene and Quaternary. In the Late Quaternary several major rivers (e.g., Sava, Drava and Danube rivers) deposited alluvial sediments (e.g., Prelogović and Velić, 1992; Velić and Durn, 1993; Velić et al., 1999).

\section{GEOLOGICAL SETTING OF THE KLOŠTAR FIELD}

An important aid in studying the structural development of this area in the Neogene and Quaternary has been a detailed palinspastical reconstruction of the Kloštar Field, spanning the Pannonian and Pontian stages, published by Velić et al. (2011). The Kloštar structure is locally defined as an anticline. This structure includes a tectonic feature, which aids study of the depositional environments and transport mechanisms in the entire depression. This is the normal fault that strikes the region of the Kloštar Field, and divides the area into two reservoir sandstone units. One is located on the hanging wall (second "series" of Late Pannonian age), and the other is located on the footwall (first "series" of Early Pontian age). This feature may explain tectonic activity during the transitions between Late Pannonian and Early Pontian and may help understand why the transport direction changed from NW-SE in the Late Pannonian to $\mathrm{N}-\mathrm{S}$ in the Early Pontian.

In the Late Pannonian, as well as in the Early Pontian, the second transtensional phase dominated the whole area of the 


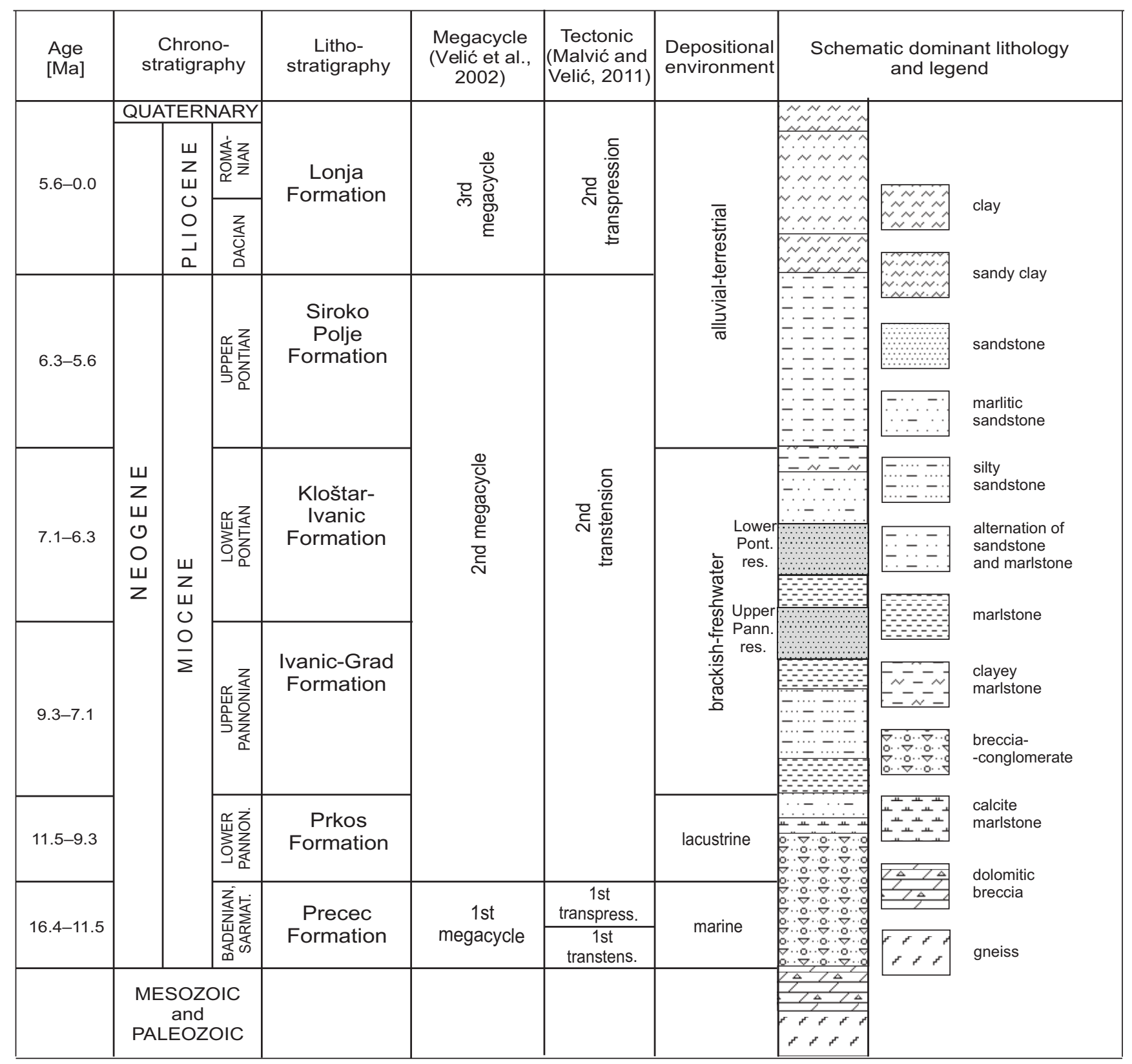

Fig. 2. Stratigraphic column, megacycles, environments, tectonic phases and lithology in the Sava Depression

CPBS. Smaller depressions (i.e. pull-apart structures) formed inside the depressions, creating new accommodation space (e.g., Horvath and Tari, 1999; Malvić and Velić, 2011). The Kloštar structure was one such pull-apart structure, where sedimentation during the second transtensional phase started with the deposition of the second sandstone "series".

The Upper Pannonian Ivanić-Grad Formation and Lower Pontian Kloštar Ivanić Formation in the Kloštar Field consist of medium-grained sandstones, mostly with quartz detritus, interbedded with marls (Fig. 2). The thickest sandstones were deposited in the central parts of a locally lowered area.

According to Velić et al. (2011), normal faulting divides the structure into two areas (NE and SW). Interestingly, the hydrocarbon-saturated sandstones of the Upper Pannonian (IvanićGrad Formation) were deposited only in the southwestern part
(Fig. 3). This is the second sandstone "series", an informal lithostratigraphic unit. The sandstones of the Lower Pontian (Kloštar Ivanić Formation) were only deposited in the northeastern part of the field (Fig. 4). They are also saturated with hydrocarbons, and informally lithostratigraphically named as the first sandstone "series". In both cases, the sandstone "series" laterally change into marl, across a wide zone with several transitional lithofacies, such as marly sandstones and sandy marlstone.

The lithofacies and depositional environment of the Upper Pannonian and Lower Pontian have also been analysed in certain cores. The Upper Pannonian and Lower Pontian reservoirs consist of sandstones, siltstones and sandy marls. During the Late Pannonian and Early Pontian, the area analysed was covered with brackish and freshwater. Sedimentation was mostly 


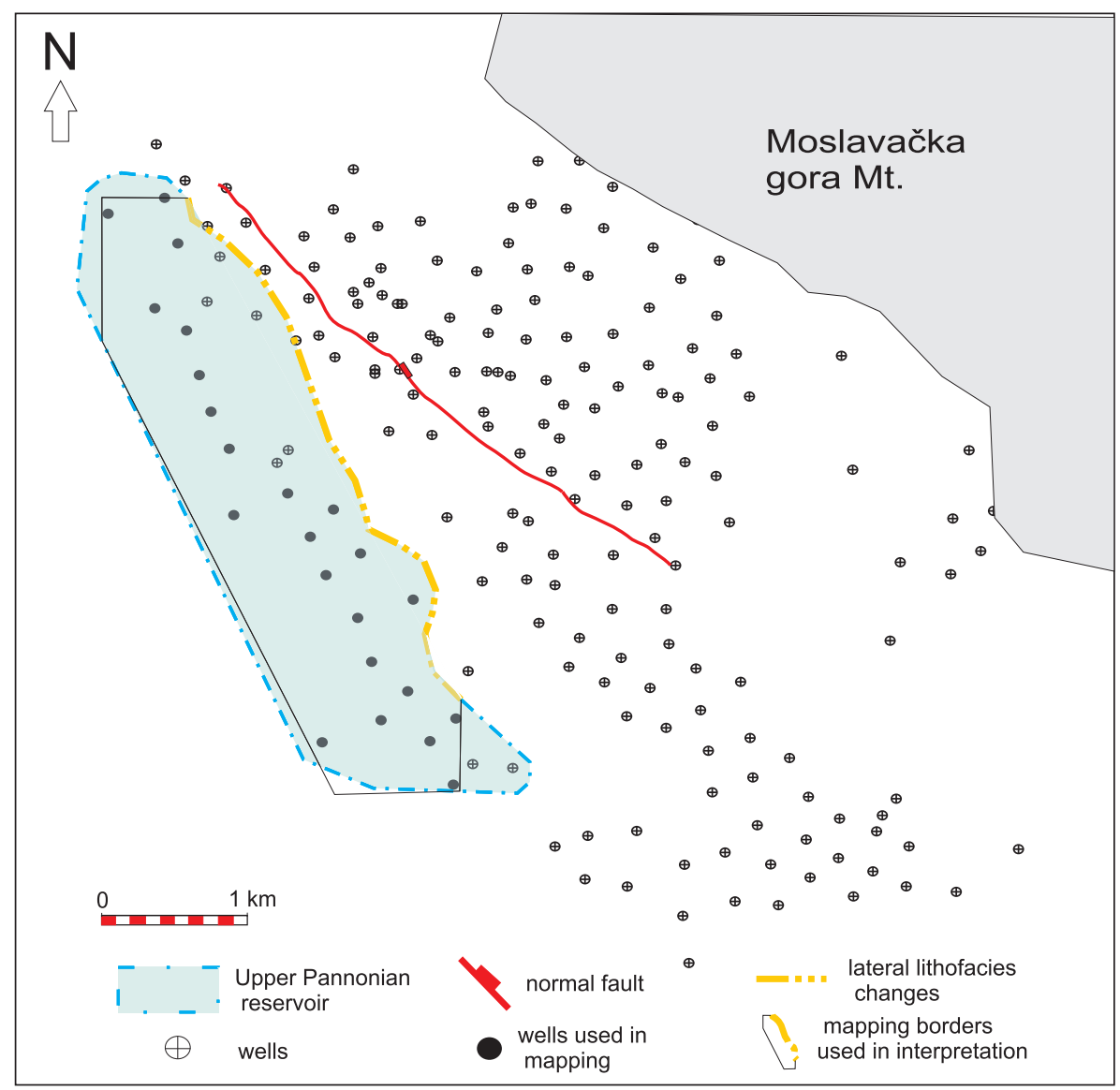

Fig. 3. Position of the Upper Pannonian reservoir

through turbidity currents. Tb, Tc and Td lithofacies of the Bouma sequence are recognized. The petrographic composition of the sandstone ( $\mathrm{Tb}$ lithofacies) is mostly uniform and it consists of quartz (82-60\%) and fragments of carbonate, schist, gneiss and granite (18-40\%). Tc and Td lithofacies have a more marly component and these comprise marly sandstones and sandy marls. The mineralogical studies did not show any recognisable differences between the Upper Pannonian and Lower Pontian reservoirs because the petrographic compositions of the Eastern Alps and Moslavačka gora Mt. are very similar. Both are represented by magmatic and metamorphic rocks and it is very hard to distinguish fragments of magmatic and metamorphic rocks derived from the Alps from those derived from Moslavačka gora Mt. However, a little sandy and silty detritus was likely transported from the Moslavačka gora Mt., presently located only a few kilometres to the north-east of the Kloštar Field. All previous palaeogeographic reconstructions (e.g., Velić et al., 2011) have shown that this distance was not significantly different during the Late Pannonian and Early Pontian.

\section{INPUT DATA FOR MAP-BASED DEPOSITIONAL ANALYSIS}

It was decided to use the porosity and thickness of the Lower Pontian and of the Upper Pannonian sandstone reser- voirs as variables to describe the heterogeneity and development of the reservoirs, i.e. different lithofacies. Thickness and porosity are connected in turbidite depositional systems in such a way that the largest thicknesses of the coarse and medium-grained sandstones usually match with a greater porosity of the same rocks. This is valid for sequences where " $\mathrm{h}$ " (total thickness) is equal or slightly higher than "he" (effective thickness). Parameters "h" and "he" are lithofacies parameters commonly used in subsurface geological mapping.

So, in the Pannonian and Pontian of the Sava Depression, other than mineral composition, the thickness and porosity are also variables of the lithofacies, because every lithofacies can always be described in terms of these two variables. Porosity values represent average well log porosities measured in 20 wells for the Lower Pontian and 17 wells for the Upper Pannonian reservoirs. Well-average porosity was used, but it was calculated only when determining the net pay of the reservoir. Spontaneous potential (SP) and resistivity ( $\mathrm{Ra}$ ) well logs were used for porosity calculations, because the wells were old and only "conventional logging" was performed in them. Furthermore, the porosity value in one of the Lower Pontian wells was extremely small compared to other well values. According to Novak Zelenika et al. (2010) this well is clearly an outlier belonging to a marl lithofacies and hence was excluded from the calculations.

Gross thickness was measured in 20 wells in the Lower Pontian reservoir, but since one Lower Pontian well was excluded, there was data from only 19 wells. In the Upper Pannonian, reservoir gross thickness was measured in 23 


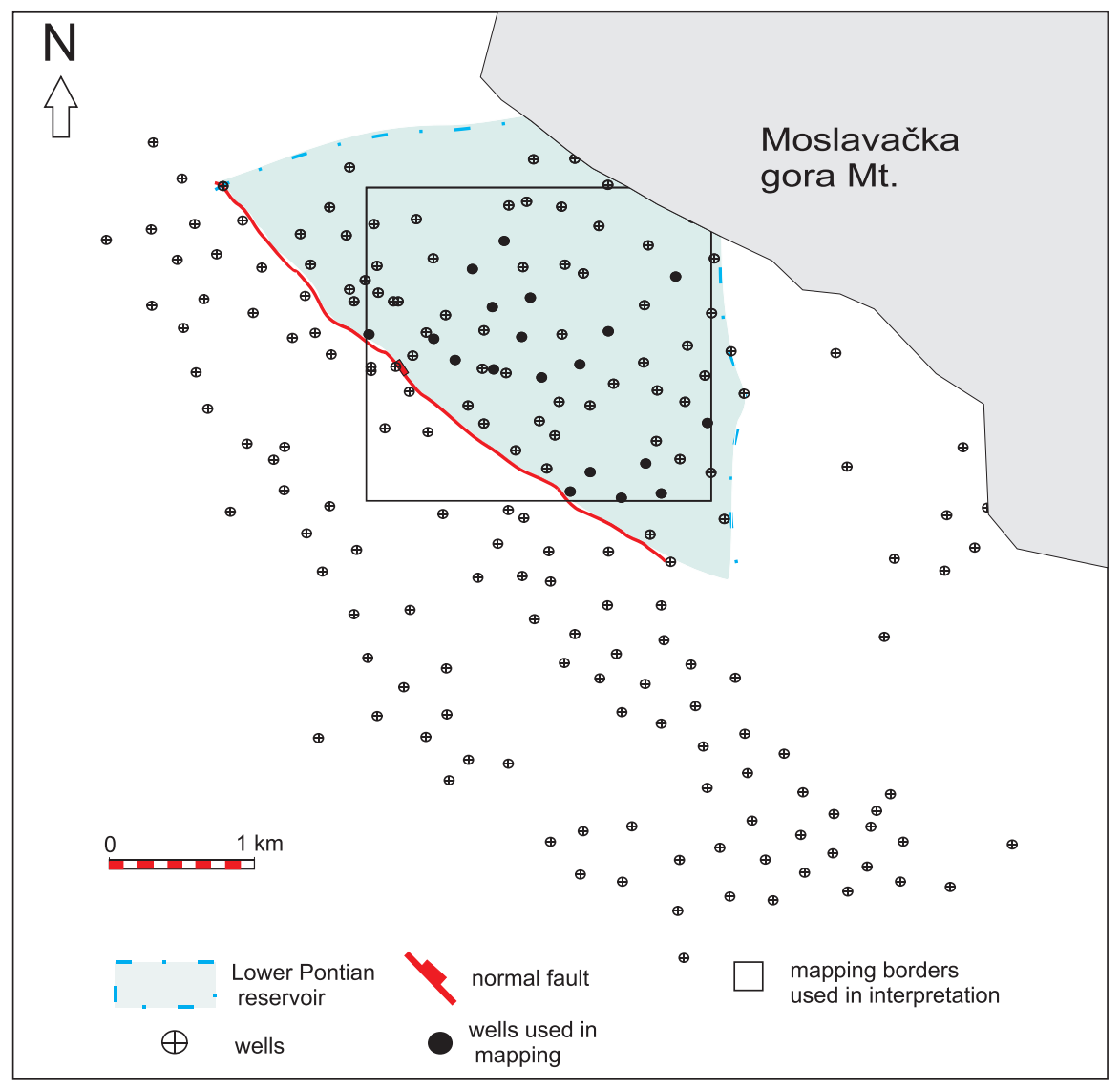

Fig. 4. Position of the Lower Pontian reservoir

wells. There were two assumptions used for mapping: (1) the more marly component is present in sandstone, the lower porosity it has, so lithofacies from pure channel sandstones and basinal marls can be identified by porosity values and (2) pure channel sandstones have greater thicknesses, compared to basinal marls.

Thickness vs. porosity charts for the Lower Pontian reservoir data and for the Upper Pannonian reservoir data are shown

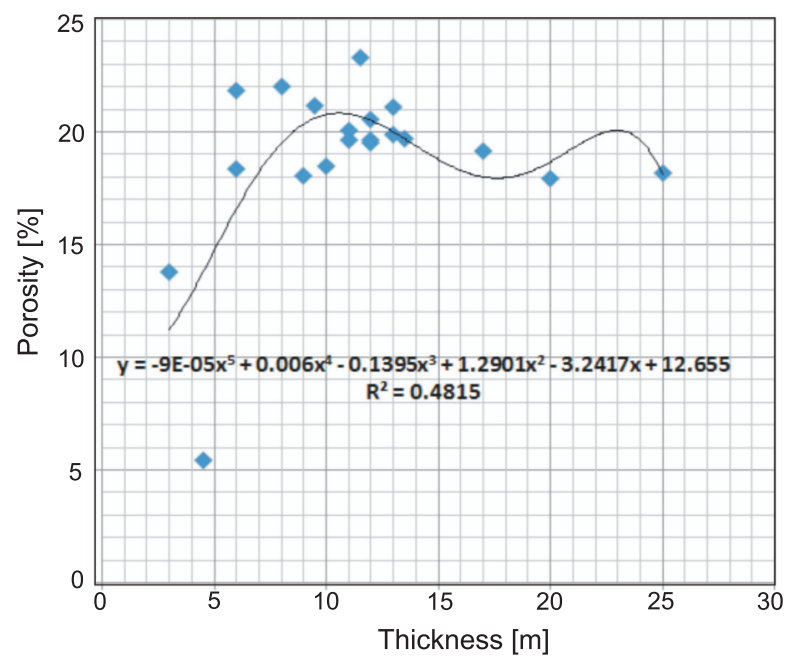

Fig. 5. Thickness vs. porosity based on Lower Pontian reservoir data in Figures 5 and 6 . At first sight they do not show any significant correlation using a coefficient of determination. But, when some outliers are excluded, there is a general trend in the porosity-thickness relationship which can be observed using regression lines.

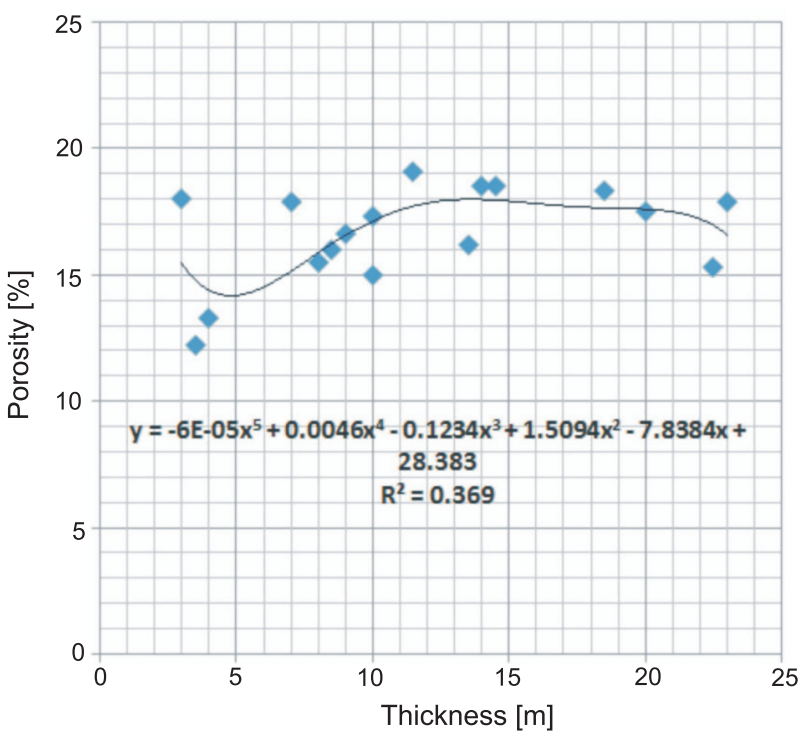

Fig. 6. Thickness vs. porosity based on Upper Pannonian reservoir data 


\section{BASICS OF APPLIED INDICATOR GEOSTATISTICAL MAPPING METHODS}

Stochastic geostatistical methods have been applied in this analysis (SIS) in order to express uncertainty. The main purpose of any stochastic simulation is to provide an estimate whilst honouring the covariance structure of the input data (i.e. input semi-variograms) and the probability distribution of the input data. When using stochastic simulations, the main emphasis is on honouring some statistical characteristics of the input set. SIS' are indicator based, which means that they use indicatory transformed data for mapping.

Basics about transformation results and Sequential Indicator Simulations

The mathematical transformation is performed by this simple equation [1]:

$$
I(x)= \begin{cases}1 & \text { if } z(x) \leq v_{\text {cutoff }} \\ 0 & \text { if } z(x)<v_{\text {cutoff }}\end{cases}
$$

where: $I(x)$ - indicator variable; $z(x)-$ measured value; $v_{\text {cutoff }}-$ cutoff value.

In indicator-based geostatistical methods, only third-order stationarity is assumed, which means that variograms are only representative statistical features. The variograms for every cutoff value had to be standardized, estimating the results in continuous intervals of $[0,1]$. SIS are stochastical geostatistical tools for spatial estimation of variable probability. The main inputs are histograms (Fig. 7) and standardized variograms. Estimations can be conditional (selected in this analysis) or unconditional.

Here, for every cutoff, variogram curves were used, so the number of cutoffs is very important. Too few cutoffs and the lithofacies transition cannot be observed, but too many classes drastically increases computational time and asks for too much point data (approx. more than 30). So, after Novak Zelenika et al. (2010) about 5 cutoffs were sufficient for reliable mapping of all expected lithofacies in depositional systems comprising sandstone-marlstone, according to the analysis they performed on sandstone reservoirs of the CPBS. Furthermore, Novak Zelenika et al. (2011) showed that forcing the normal distribution of transformed data can also improve final maps. Both of these assumptions were used in this study, although it was ben- eficial that the original reservoir data already mostly followed a normal distribution, as shown on Figure 7 for measured (averaged) thicknesses in both reservoir "series".

\section{INTERPOLATED MAPS OF UPPER PANNONIAN AND LOWER PONTIAN RESERVOIR VARIABLES}

As already mentioned, the Upper Pannonian and Lower Pontian strata were mapped by SIS methods. The average porosity and real thickness were selected as the individual variables for the largest hydrocarbon reservoir in the first (Lower Pontian reservoir) and second (Upper Pannonian reservoir) "series". Those reservoirs are the depositional units that cover the largest parts of the downthrown area in the Kloštar structure during particular stages and laterally they change gradually into marly sandstone, sandy marlstone and eventually marlstone.

\section{INTERPOLATED MAPS}

\section{OF THE UPPER PANNONIAN STRATA}

For the Upper Pannonian data, 6 classes were selected using the following cutoffs: $13,15,16,18,19$ and $20 \%$ for porosity and 3, 7, 9, 15, 21 and $23 \mathrm{~m}$ for thickness. Selection of the cutoffs was the hardest part in the analysis. The real problem was lack of exact measurements or lithological descriptions, where both variables could be compared. There were 25-35 measurements either of porosity or of lithology, but the depth intervals did not match. However, porosity and thickness are organised in classes in which the histograms follow a normal distribution. As it was mentioned, according to Novak Zelenika et al. (2010) at least 5 cutoffs as a minimum are desirable and this was one of the criteria used to define a cutoff.

Indicator data was transformed for each cutoff and variogram surface maps were calculated for the indicator datasets, showing the direction of the primary $\left(135-315^{\circ}\right)$ and the secondary $\left(45-225^{\circ}\right)$ axis. Experimental variograms were standardized and approximated with theoretical ones. Eventually, 100 realizations were calculated for each cutoff and variable. The selected probability maps for porosity are shown in Figure 8, and the maps for thickness are shown in Figure 9. Selection was done based on cutoffs, where palaeotransport directions could be most easily observed.
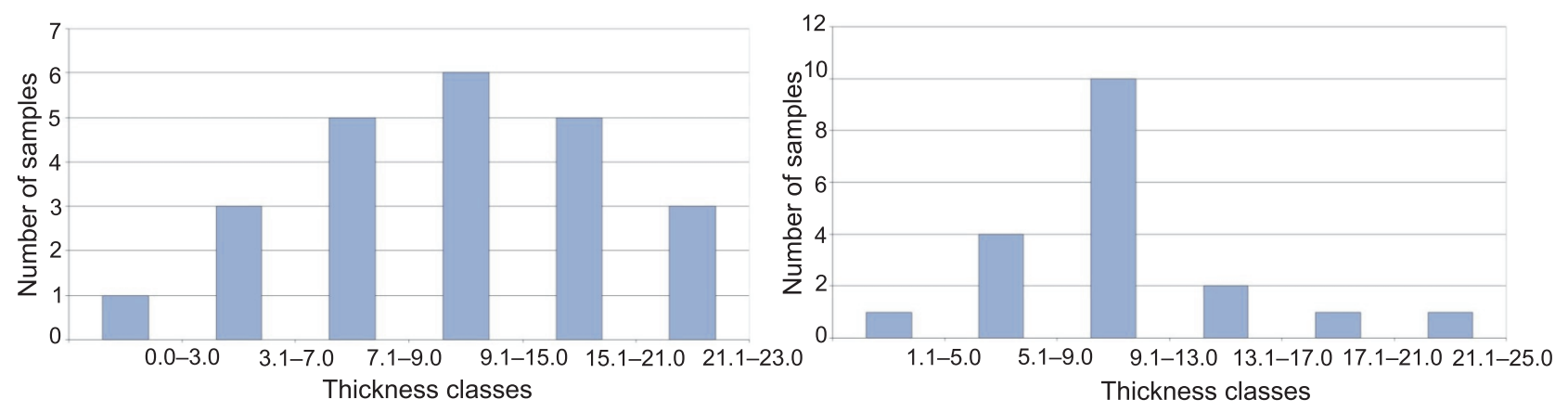

Fig. 7. Normal distribution shown on histograms of original thickness data collected in the second (left) and first (right) reservoir "series" (Novak Zelenika et al., 2011) 
INTERPOLATED MAPS

OF THE LOWER PONTIAN STRATA

The following cutoffs were selected: 14, 18, 19, 20 and $22 \%$ for porosity and 5, 9, 13, 17, $21 \mathrm{~m}$ for thickness. Criteria for cut- off selection were the same as those described above. Experimental variograms were standardized and approximated with theoretical curves. Probability maps, with selected cutoffs that show characteristic depositional patterns, are shown in Figures 10 and 11.
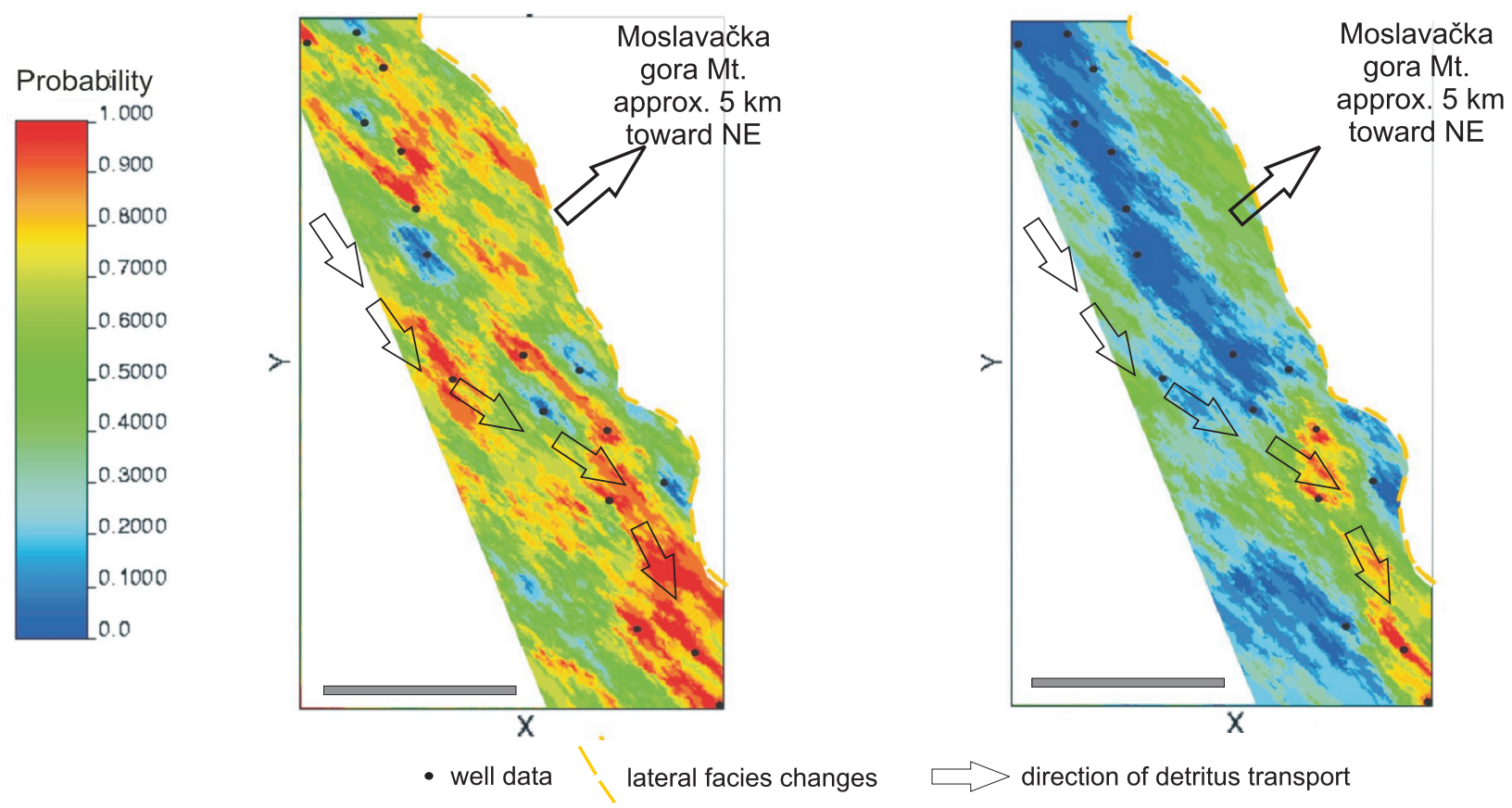

Fig. 8. Probability maps for porosity $>16 \%$ (left) and $18 \%$ (right) - Upper Pannonian
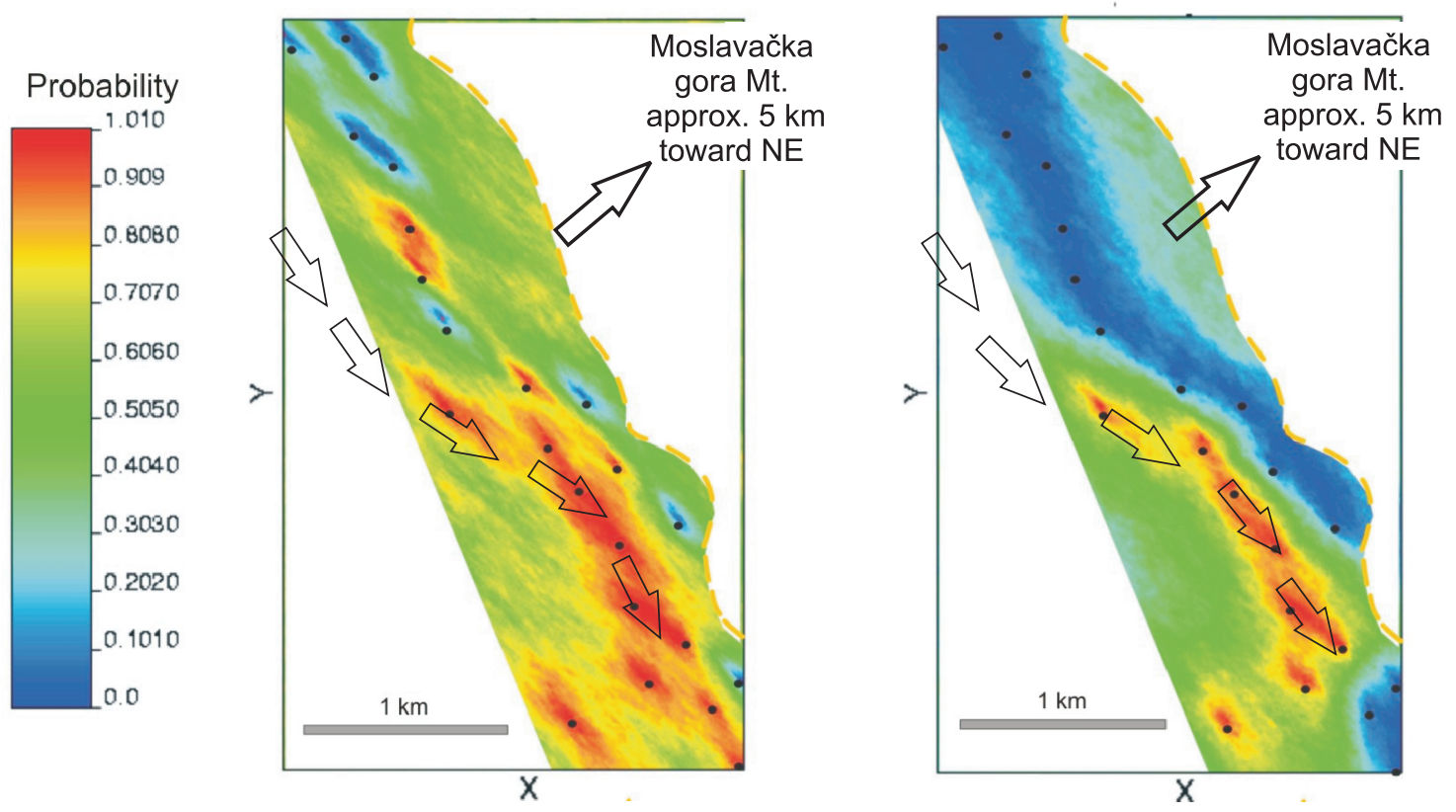

Fig. 9. Probability maps for thickness $>9 \mathrm{~m}$ (left) and $15 \mathrm{~m}$ (right) - Upper Pannonian (modified after Novak Zelenika et al., 2011)

For explanations see Figure 8 


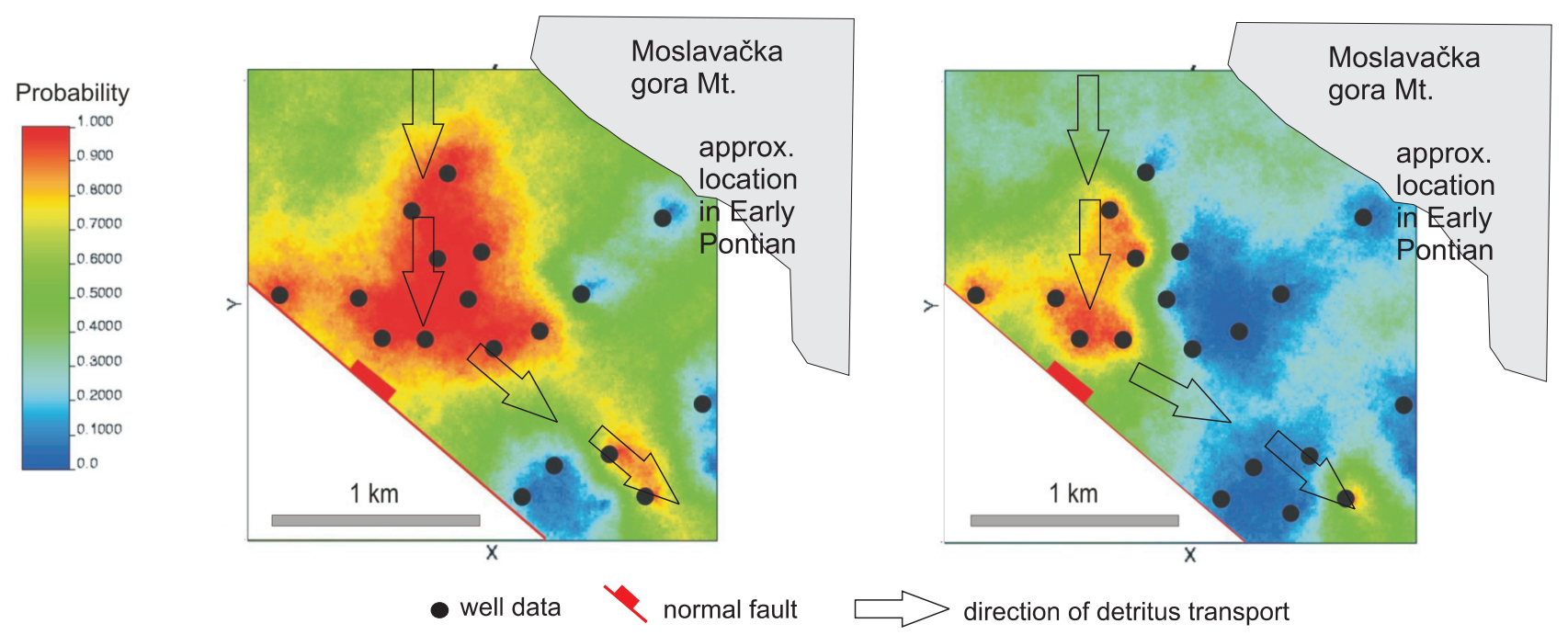

Fig. 10. Probability maps for porosity $>19 \%$ (left) and $20 \%$ (right) - Lower Pontian

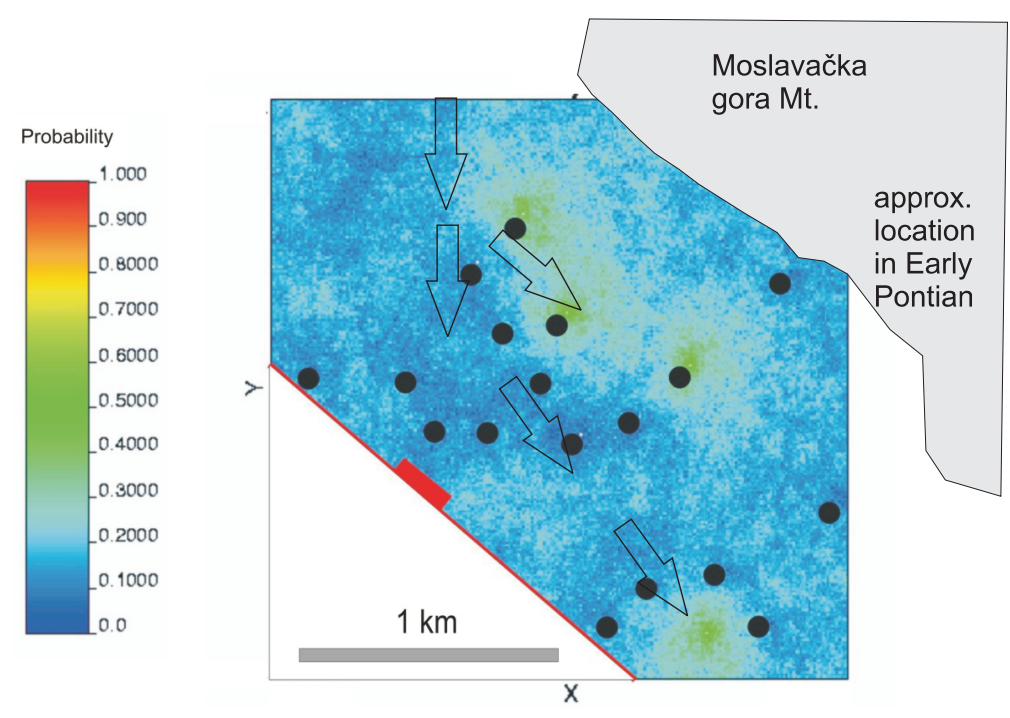

Fig. 11. Probability maps for thickness $>13 \mathrm{~m}$ - Lower Pontian (modified after Novak Zelenika and Malvić, 2011)

For explanations see Figure 10

\section{GEOLOGICAL INTERPRETATION OF MAPS}

The highest probabilities that porosity and thickness of Upper Pannonian reservoir are larger than 16 and $18 \%$, i.e. 9 and $15 \mathrm{~m}$, are easily followed in Figures 8 and 9. Those two maps can be compared by trends and features onto ordinary kriging (OK) maps of the same variables (Figs. 12 and 13). It is clear that the deepest part of the basin strikes in a northwest-southeast direction. The OK maps also show that reservoir thickness and porosity decrease towards the east. Lower porosity and thickness observed in Figures 12 and 13 directly indicate a thin- ning of the reservoir. Towards the east, the reservoir sandstone contains a more marly component, and the course of lateral facies changes can be inferred. Reservoir properties, based on production data, can be added to sandstone and marly sandstone lithofacies. These sediments were deposited in environments where the depth was predominantly $\mathbf{2 0 0} \mathrm{m}$ or less (Vrbanac et al., 2010).

Between the Late Pannonian and Early Pontian a regional normal fault formed along the margin of the Moslavačka gora Mt., and caused the lowering of the northeastern part of the Kloštar structure. This resulted in the opening up of a new accommodation area for the Lower Pontian sandstones (Velić et al., 2011). At the same time, according to Vrbanac et al. (2010), the direction of turbidity inflows into the Sava Depression changed to $\mathrm{N}-\mathrm{S}$, as they were being influenced by the Moslavačka gora Mt. palaeorelief. These directional changes should be clearly seen in the porosity and thickness maps, therefore the SIS maps obtained (Figs. 10 and 11) were combined with OK maps (Figs. 14 and 15) to interpret the depositional directions and environments.

The north-south direction of turbidity currents in the Lower Pontian succession can be indirectly observed on Figures 10 and 11 . Higher porosity values are easily identifiable in the western part and are interpreted to reflect a process whereby coarser material, transported from the north through the deepest basinal part, reached the main fault zone and continued to flow parallel to it farther towards the south-east (Fig. 15).

According to the general depositional model for the CPBS (e.g., Malvić and Velić, 2011; Velić et al., 2011) the coarsest detritus delivered by turbidity currents was deposited in the deepest part of the depressions. Consequently, sandstones with the highest porosity (coarse or medium-grained) have the greatest thicknesses. In the area analysed, such matching is only valid 


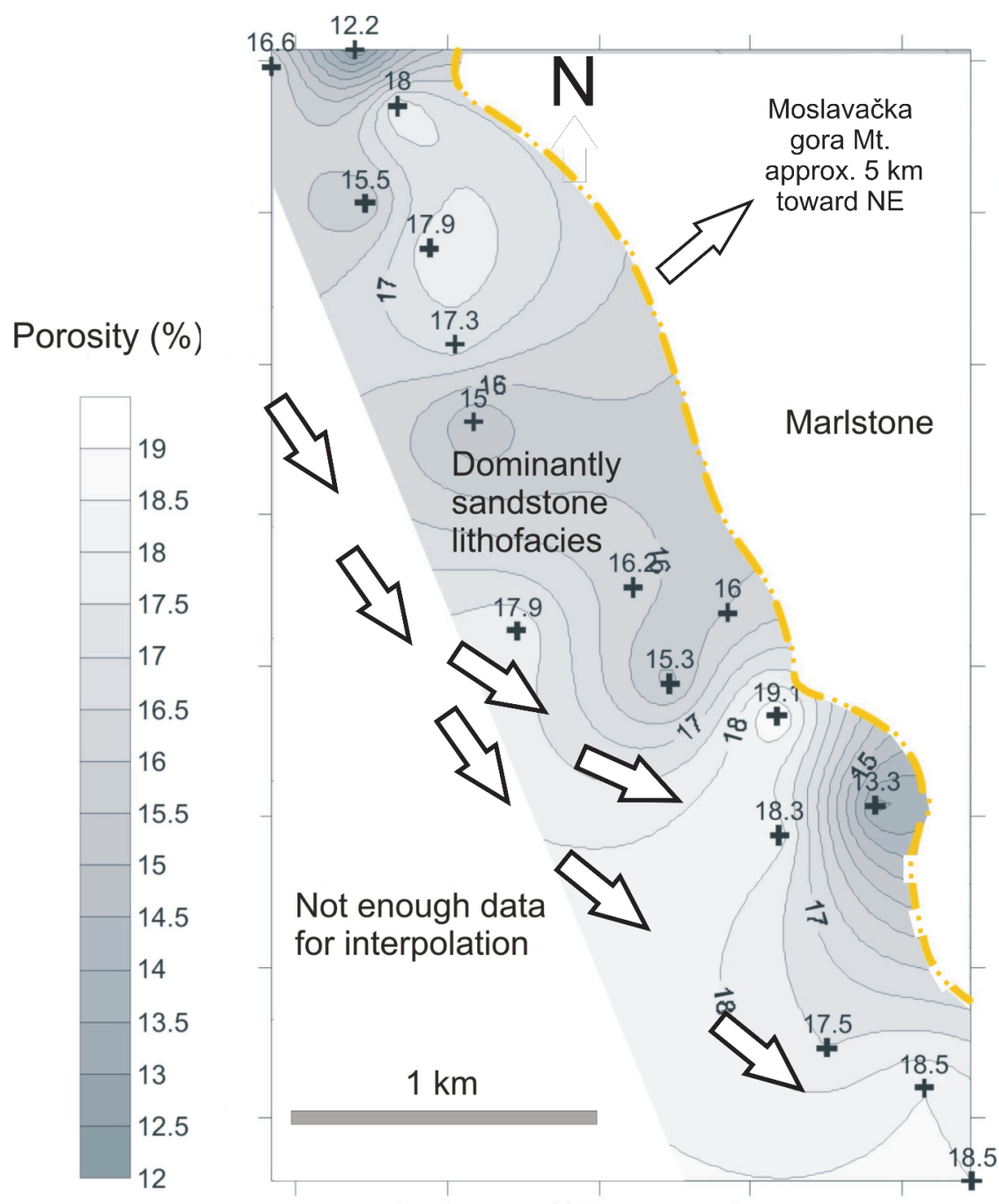

Fig. 12. Ordinary kriging porosity map of the Upper Pannonian reservoir

For explanations see Figure 8

for parts with higher porosities. The same can be seen in probability maps (Figs. 10 and 11), where the highest probability of the largest porosities (more than 19 and 20\%) only partially matches the highest probability of the reservoir part thicker than $13 \mathrm{~m}$. With regard to classical turbidite theory (e.g., Bouma, 1962; Tišljar, 1994) the lithofacies Tb dominates in the middle part of the Kloštar structure, which was also the deepest part through the second transtensional phase. The Tb interval was clearly observed in cores taken from sandstone interval saturated with hydrocarbons. However, the cores had been taken only from the cap rocks, i.e. marls that represent pelitic facies $\mathrm{Te}$, so the vertical transition from $\mathrm{Tb}$ to Te was not observed in continuity. However, the lateral transition from $\mathrm{Tb}$ to $\mathrm{Te}$ has been clearly observed in fine turbidite deposits (such as Tc and Td lithofacies that correspond to porosity less than 19\%; Fig. 10) which are carried in suspension and were deposited over the main channels, i.e. onto the basin plain around them. The Tb lithofacies is also present in the depocentre situated in the south. This small depocentre was separated from the central part by smaller, uplifted palaeorelief.

Turbidity currents, after reaching the Kloštar structure, were losing their energy and turbidites becomes more distal with in- creasing distance from the western margin of the Moslavačka gora Mt. Consequently, farther to the south-east marly sandstones (and siltstones) are dominant (Tc and Td lithofacies); the average porosity is lower but the total gross thickness of the Lower Pontian reservoir is the same retained due to weaker erosion at turbidity current bases.

Two lithofacies maps (sandstone/shale ratio, i.e. ss/sh) were created (Figs. 16 and 17). This ratio is simply the total thickness of permeable strata divided by the total thickness of relatively impermeable parts, for a given thickness of reservoir selected. The ss/sh maps have very specific properties reflected in applied equidistance, which are strictly defined through the following fractions: $128 / 1$ (pure sandstone), 64/1, $32 / 1,16 / 1,8 / 1,4 / 1,2 / 1,1 / 1,1 / 2,1 / 4,1 / 8,1 / 16,1 / 32,1 / 64$ and $1 / 128$ (pure marl).

The maps clearly show the locations of the pure sandstones. The transport direction NW-SE can be observed in the ss/sh map of the Upper Pannonian reservoir (Fig. 16) and matches well with that derived from the ordinary kriging porosity and thickness maps (Figs. 12 and 13).

The transport direction in the Early Pontian can be easy observed in the ss/sh maps (Fig. 17). Actually, according to the 


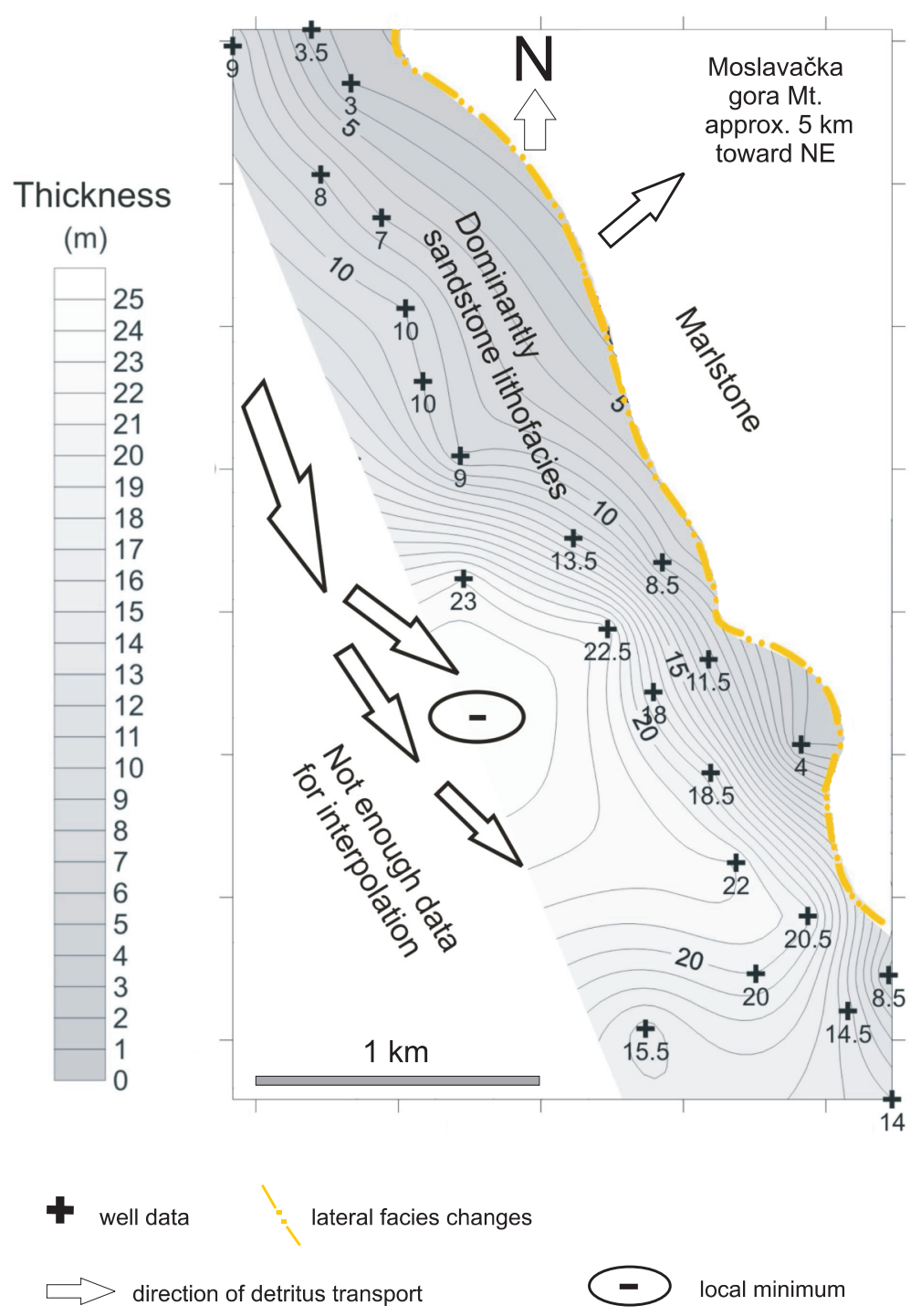

Fig. 13. Ordinary kriging thickness map of the Upper Pannonian reservoir

distribution of pure sandstones on the same map, it can also be concluded that the transport direction during the Early Pontian was not just N-S, but also NE-SW. Since the location of the Moslavačka gora Mt. in the Early Pontian was in the NE, it is very logical to conclude that some material came from there and mixed with detritus coming from the Eastern Alps. The different probabilities for porosities higher than 19 and $20 \%$ of the Lower Pontian reservoir (Fig. 10) in the western and eastern parts also indicate the Moslavačka gora Mt. as the source of local material.

\section{CONCLUSIONS}

The entire second transtension phase was dominated by a northwest-southeast palaeoflow direction. Our results point also to north-south, or even to northeast-southwest directions in the Early Pontian, when the Moslavačka gora Mt. was a dominant palaeorelief feature in the western Sava Depression. Such a regional uplifted structure was probably a local source of detritus during the Late Miocene, although most of material came from the Eastern Alps.

Mineralogically it is impossible to distinguish material from the Eastern Alps and Moslavačka gora Mt., because both sources are represented by very similar magmatic and metamorphic rocks. However, since the sandstone composition is also very similar between the Upper Pannonian and Lower Pontian sandstones in the Kloštar Field, the influence of the Moslavačka gora Mt. as a local material source was not proven, but there is considerable indirect evidence for such an assumption. The mapping results shows that:

- coarsest material in the Late Pannonian was deposited in the deepest parts of the Kloštar structure;

- almost complete turbidite Bouma sequences were developed. The intervals from Tb to Td (i.e. Tb, Tc, and Td) are recognized in the cores;

- towards the north and north-east shallow lacustrine pelitic sedimentation was continual. 


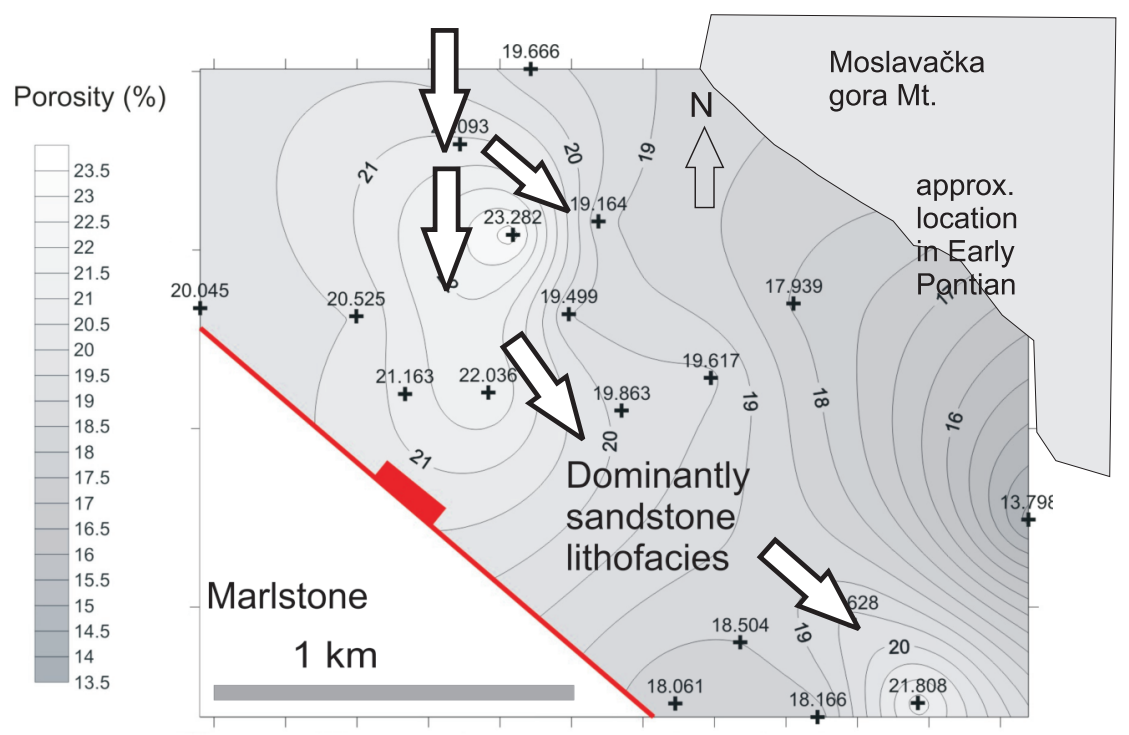

Fig. 14. Ordinary Kriging porosity map of the Lower Pontian reservoir

For explanations see Figure 10

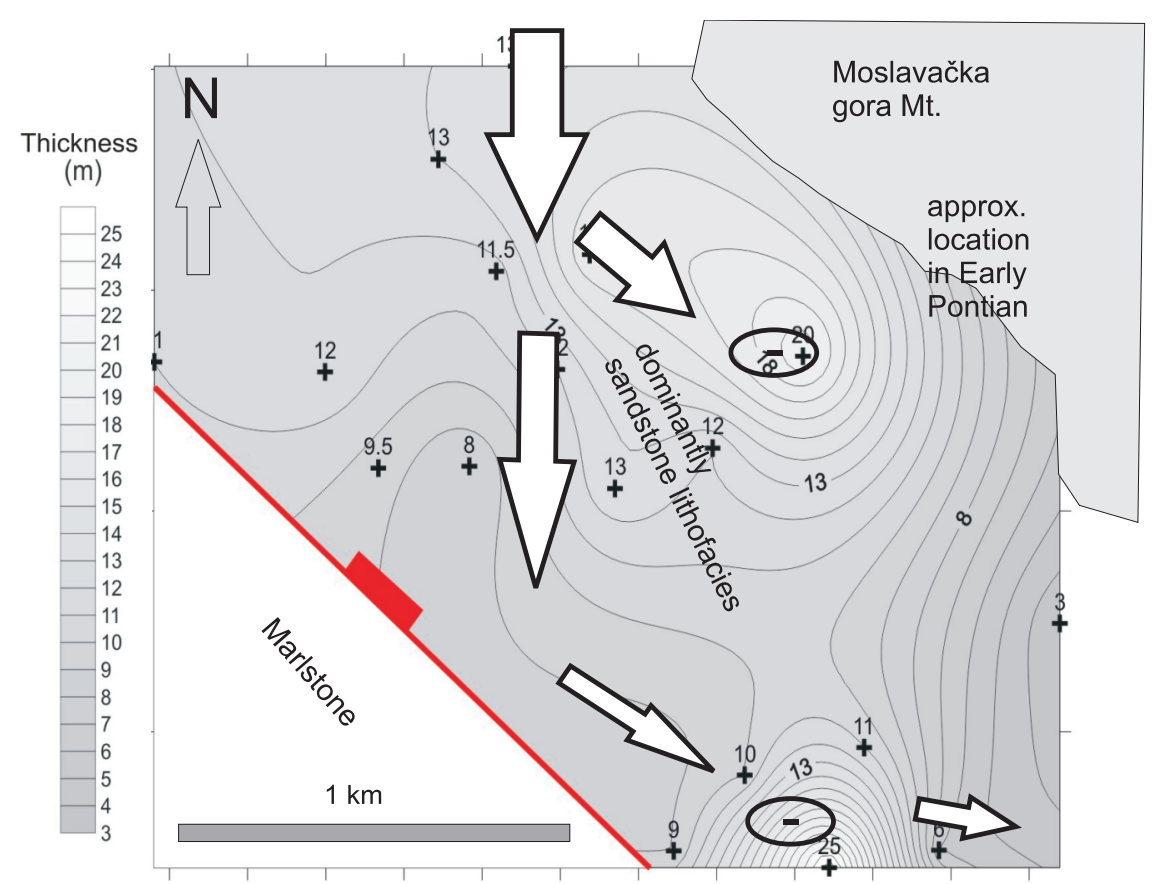

Fig. 15. Ordinary Kriging thickness map of the Lower Pontian reservoir

For explanations see Figure 10

In the SIS maps for the Late Pannonian a general NW-SE depositional trend can be clearly seen (Figs. 8 and 9). However, a transport direction change can be observed in the Lower Pontian reservoir, where the porosity and thickness maps (Figs. 10 and 11), as well as the ss/sh map (Fig. 17) indicate the existence of two directions, i.e. north-south and northeast-southwest. This partial change in direction is attributed to the strong influence of the uplift of the Moslavačka gora Mt., with erosion on its surface, and small alluvial fans. Unfortunately, the quantitative share in total deposited volume cannot be calculated, because the slight differences in mineral composition of the Upper Pannonian and Lower Pontian cores cannot be directly connected with the Moslavačka gora Mt. outcrops. 


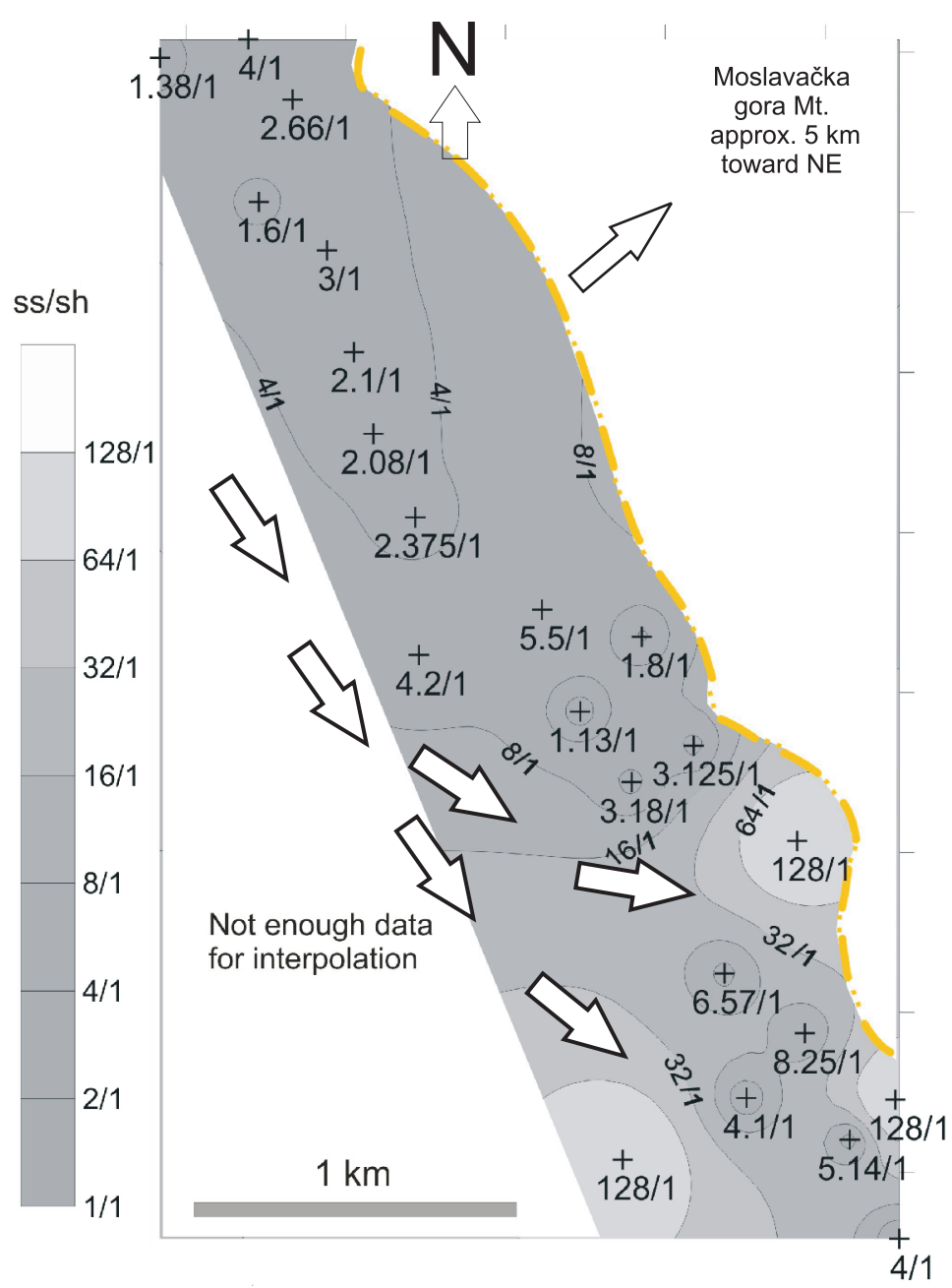

Fig. 16. Sandstone/shale (Ss/sh) map of the Upper Pannonian reservoir For explanations see Figure 8

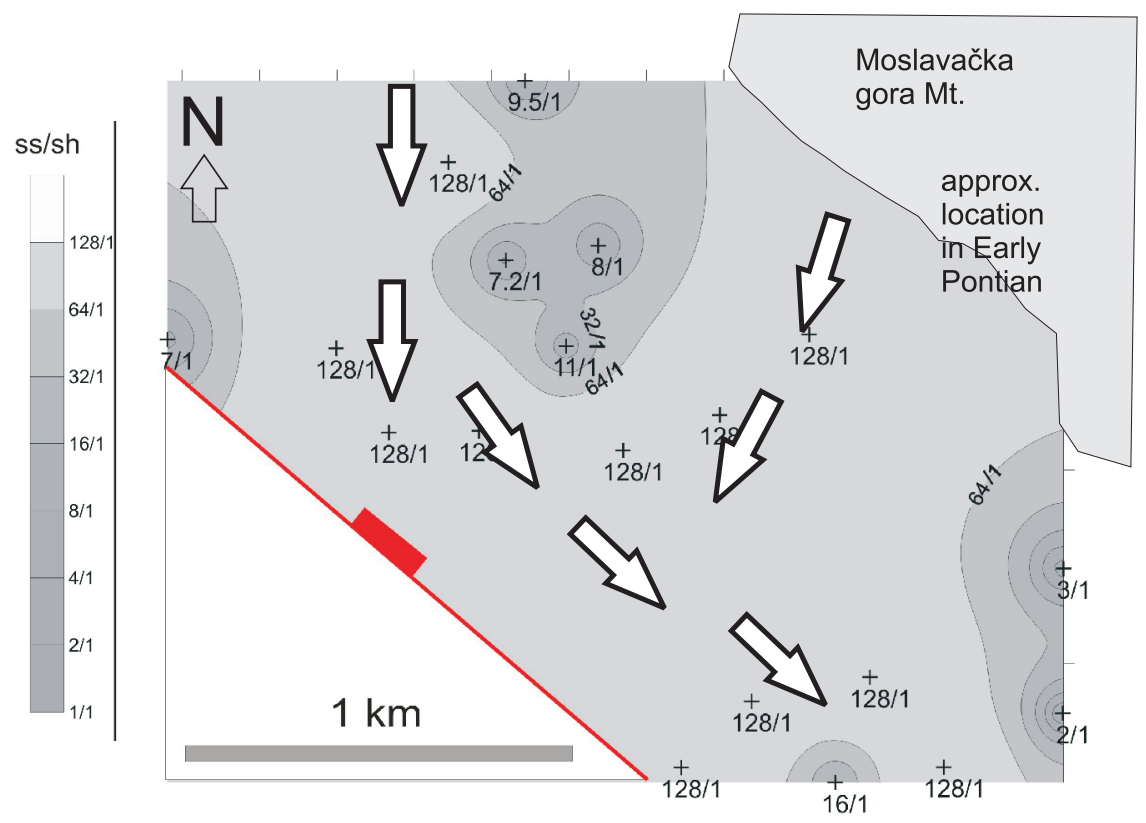

Fig. 17. Ss/sh map of the Lower Pontian reservoir

For explanations see Figure 10 
Acknowledgments. This work represents part of a multidisciplinary geological research project entitled "Stratigraphical and geomathematical research of petroleum geological systems in Croatia" (project no. 195-1951293-0237), which is financed by the Ministry of Science, Education and Sports of the
Republic of Croatia. We would like to thank the reviewers, B. Vrbanac, and one anonymous, and in particular S. Porębski for their advice to improve our manuscript.

\section{REFERENCES}

Bouma A.H. (1962) Sedimentology of some flysch deposits: a graphic approach to facies interpretation. Elsevier, Amsterdam.

Ćorić S., Pavelić D., Rögl F., Mandic O., Vrabac S., Avanić R., Jerković L., Vranjković A. (2009) Revised Middle Miocene datum for initial marine flooding of North Croatian Basins (Pannonian Basin System, Central Paratethys). Geologia Croatica, 62 (1): 31-43.

Hailwood E., Ding F. (2000) Sediment transport and dispersal pathways in the Lower Cretaceous sands of the Britannia Field, derived from magnetic anisotropy. Petroleum Geoscience, 6: 369-379.

Horvath F., Tari G. (1999) IBS Pannonian Basin Project: a review of the main results and their bearings on hydrocarbon exploration. Geological Society London, Special Publication, 156: 195-213.

Kovačić M., Horvat M., Pikija M., Slovenec D. (2011) Composition and provenance of Neogene sedimentary rocks of Dilj gora Mt. (south Pannonian Basin, Croatia). Geologia Croatica, 64 (2): 121-132.

Krezsek C., Filipescu S. (2005) Middle to Late Miocene sequence stratigraphy of the Transylvanian Basin (Romania). Tectonophysics, 410 (1-4): 437-463.

Krezsek C., Filipescu S., Silye L., Matenco L., Doust H. (2010) Miocene facies associations and sedimentary evolution of the Southern Transylvanian Basin (Romania): implications for hydrocarbon exploration. Marine and Petroleum Geology, 27: 191-214.

Malvić T. (2012) Miocene depositional environments in shallow sea and lake, Northern Croatia - a review. Geological Quarterly, $\mathbf{5 6}$ (3): 493-504.

Malvić T., Velić J. (2011) Neogene tectonics in Croatian Part of the Pannonian Basin and reflectance in hydrocarbon accumulations. In: New Frontiers in Tectonic Research: at the Midst of Plate Convergence (ed. U. Schattner): 215-238. InTech.

Malvić T., Velić J., Peh Z. (2005) Qualitative-quantitative analyses of the influence of depth and lithological composition on Lower Pontian sandstone porosity in the central part of Bjelovar Sag (Croatia). Geologia Croatica, 58 (1): 73-85.

Novak Zelenika K., Malvić T. (2011) Stochastic simulations of dependent geological variables in sandstone reservoirs of Neogene age: a case study of Kloštar Field, Sava Depression. Geologia Croatica, 64 (2): 173-183.

Novak Zelenika K., Malvić T., Geiger J. (2010) Mapping of the Late Miocene sandstone facies using Indicator Kriging. Nafta, 61 (5): 225-233.

Novak Zelenika K., Velić J., Malvić T., Cvetković M. (2011) Geological variables fitting in normal distribution and application in indicator geostatistical methods. Proc. IAMG, 2011 Conference, Natural Science Building of Salzburg University, Austria, September 5-9, 2011. GIScience and OAW: 245-251.

Prelogović E., Velić J. (1992) Correlation of Quaternary sediments and tectonic activity of the eastern part of the Drava River Depression. Geologia Croatica, 45: 151-162.

Rögl F. (1996) Stratigraphic correlation of the Paratethys Oligocene and Miocene. Mitteilungen der Gesellschaft der Geologie- und Bergbaustudenten in Österreich, 41: 65-73.

Rögl F. (1998) Palaeographic consideration for Mediterranean and Paratethys seaways (Oligocene to Miocene). Annalen des Naturhistorisches Museums in Wien, 99A: 279-310.

Rögl F., Steininger F. (1984) Neogene Paratethys, Mediterranean and Indo-Pacific seaways. Geological Journal, Special issue, 11: 171-200.

Royden L.H. (1988) Late Cenozoic tectonics of the Pannonian Basin System. AAPG Memoir, 45: 27-48.

Tišljar J. (1994) Sedimentne stijene. Školska knjiga, Zagreb.

Velić J. (2007) Geologija ležišta nafte i plina. Faculty of Mining, Geology and Petroleum Engineering, University of Zagreb.

Velić J., Durn G. (1993) Alternating lacustrine-marsh sedimentation and subaerial exposure phases during Quaternary: Prečko, Zagreb, Croatia. Geologia Croatica, 46 (1): 71-90.

Velić J., Saftić B., Malvić T. (1999) Lithologic composition and stratigraphy of Quaternary sediments in the area of the "Jakuševec" Waste Depository (Zagreb, Northern Croatia). Geologia Croatica, 52 (2): 119-130.

Velić J., Weisser M., Saftić B., Vrbanac B., Ivković Ž. (2002) Petroleum-geological characteristics and exploration level of the three Neogene depositional megacycles in the Croatian part of the Pannonian basin. Nafta, 53 (6-7): 239-249.

Velić J., Malvić T., Cvetković M. (2011) Palinspastic reconstruction of synsedimentary tectonics of Neogene and Quaternary sediments in the Kloštar Field (Sava Depression, Pannonian Basin, Croatia). Zeitschrift der Deutschen Gesellschaft für Geowissenschaften, 162 (2): 193-203.

Vrbanac B. (2002) Facies and facies architecture of the Ivanić Grad Formation (Upper Pannonian) - Sava Depression, NW Croatia. Geologia Croatica, 55 (1): 57-77.

Vrbanac B., Velić J., Malvić T. (2010) Sedimentation of deep-water turbidites in main and marginal basins in the SW part of the Pannonian Basin. Geologica Carpathica, 61 (1): 55-69. 